[Agr. Biol. Chem., Vol. 32, No. 10, p. 1205 1211, 1968]

\title{
Microbial Conversion of Petro-sulfur Compounds
}

\section{Part II. Culture Conditions of Dibenzothiophene-Utilizing Bacteria*}

\author{
By Shigeru Nakatani, Toshio Akasaki, Koki Kodama**, \\ Yasuji Minoda ${ }^{* *}$ and Koichi Yamada** \\ Central Research Institute of Electric Power Industry, Abiko, Chiba Prefecture \\ **Department of Agricultural Chemistry, Faculty of Agriculture, \\ The University of Tokyo \\ Received April 8, 1968
}

\begin{abstract}
In order to enhance the efficiency converting dibenzothiophene (DBT) into water-soluble compounds by DBT-utilizing bacteria, the following subjects were studied: comparison of activities of isolated strains, their mixed cultivation, DBT dosing, nitrogen sources, substrate concentration, $\mathrm{pH}$, temperature, and oxygen supply. Light oil solution of DBT $(5 \%)$ was used as substrate. The conversion efficiency was calculated by the amount of sulfur accumulated in the aqueous layer of culture broth.

The conversion ratio of $40 \%$ was attained by the mixed culture of Pseudomonas abikonensis and $P_{s}$. jianii under the following conditions; medium, DBT $4.6 \mathrm{~g}$ dissolved in $87.8 \mathrm{~g}$ of light oil, meat extract $4.0 \mathrm{~g}, \mathrm{Na}_{2} \mathrm{HPO}_{4} \cdot 12 \mathrm{H}_{2} \mathrm{O} 9.5 \mathrm{~g}, \mathrm{KH}_{2} \mathrm{PO}_{4} 1.4 \mathrm{~g}, \mathrm{MgCl}_{2} \cdot 6 \mathrm{H}_{2} \mathrm{O}$ $0.2 \mathrm{~g}$, distilled water $1000 \mathrm{ml} ; \mathrm{pH}, 6.9$ to 7.3 ( $\mathrm{M} / 30$ phosphate buffer); oxygen supply, $50 \mathrm{ml}$ broth $500 \mathrm{ml}$ flask, shake culture at $220 \mathrm{rpm}$; inoculum size, 10\%; temperature, $28^{\circ} \mathrm{C}$; and period of cultivation, 3 days.
\end{abstract}

As reported in the previous paper, ${ }^{11}$ six strains of bacteria capable of converting DBT into water-soluble forms were isolated. The work of isolation of DBT-utilizing bacteria was continued further, and three bacterial strains, DDE 27-2, DDE 27-3 and DDE 27-4, were newly obtained.

This report deals with the taxonomic studies and the culture conditions of the new isolates.

\section{MATERIALS AND METHODS}

Microorganisms. Three strains of bacteria DDE 27-2, DDE 27-3 and DDE 27-4, were used in addition to six strains of the DBT-utilizing bacteria reported in the previous paper (DDC 327, DDE 188, DDE 206,

* This paper was read in part at the Annual Meeting of the Agricultural Chemical Society of Japan, April 4, 1967.

1) K. Yamada, Y. Minoda, K. Kodama, S. Nakatani, and T. Akasaki, Agr. Biol. Chem., 32, 840 (1968).
Ps. abikonensis DDA 109, and Ps. jianii DDG 279 and DDE 27-1).

Cultivation. One to five $\mathrm{ml}$ of seed culture, having been precultured in submerged broth for 2 days, was inoculated into $50 \mathrm{ml}$ of the medium. Incubation was carried out at $28^{\circ} \mathrm{C}$ on a rotary shaker $(220 \mathrm{rpm}, 7 \mathrm{~cm}$ dia.) or a reciprocal shaker (110

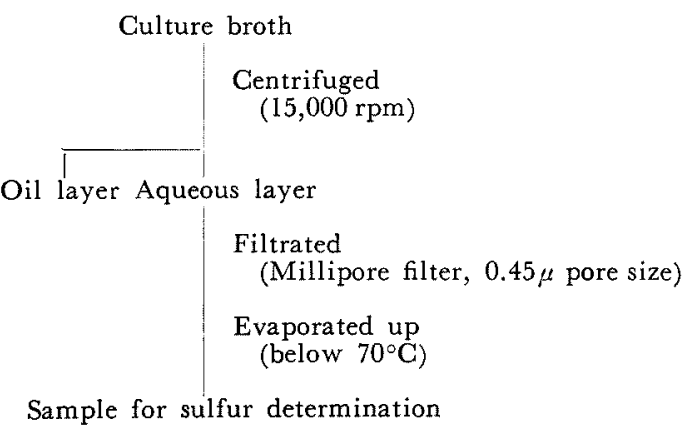

Oil layer Aqueous layer

Filtrated (Millipore filter, $0.45 \mu$ pore size)

Evaporated up (below $70^{\circ} \mathrm{C}$ )

Sample for sulfur determination

FIG. 1. Preparation of Sample for Sulfur Determination. 
strokes per $\min , 7 \mathrm{~cm}$ amplitude) for 3 to 10 days using $500 \mathrm{ml}$ flask unless otherwise stated. The growth was measured by optical density at $660 \mathrm{~m} \mu$.

Determination of sulfur. The conversion efficiency was calculated by the amount of sulfur accumulated in the aqueous layer of culture broth. After cultivation broth was treated as shown in Fig. 1. One part of dried culture filtrate was combusted in a quartz combusion tube, ${ }^{21}$ and sulfate resulted was determined by titration with barium perchlorate solution. ${ }^{31}$

\section{RESULTS AND DISCUSSION}

Taxonomic studies of new isolates

Three bacterial strains, DDE 27-2, DDE 27-3 and DDE 27-4, were isolated newly from the enrichment culture, ${ }^{11}$ from which $P$ s. jianii DDE $27-1$ had been isolated. The new isolates, pertaining to $P$ s. jianii as shown in Table I, differ each other in ability to convert DBT into water-soluble form.

Table I. Descriptive Chart of the Isolated Microorganisms

\begin{tabular}{|c|c|c|c|}
\hline & Ps. jianii & \multicolumn{2}{|c|}{ New isolates } \\
\hline & DDE 27-1 & DDE $27-2$ & DDE $27-3$, DDE $27-4$ \\
\hline Shape & Rods & Short rods & Rods \\
\hline Size $(\mu)$ & $0.5 \times 1.0 \sim 1.5$ & $0.6 \times 1.2 \sim 1.4$ & $0.6 \times 1.4 \sim 1.8$ \\
\hline Flagella & Polar (tuft) & Polar (tuft) & Polar (tuft) \\
\hline Gram-stain & Negative & Negative & Negative \\
\hline Pigmentation & No pigmentation & No pigmentation & No pigmentation \\
\hline Glutamate agar slant & Growth moderate & Growth moderate & Growth moderate \\
\hline Nutrient gelatin stab & No liquefaction & No liquefaction & No liquefaction \\
\hline Litmus milk & & Unchanged & Slowly coagulated \\
\hline B. C. P. milk & $\begin{array}{l}\text { Slightly acid, slowly } \\
\text { coagulated }\end{array}$ & Slightly alkaline & Acid, coagulated \\
\hline $\mathrm{NO}_{3} \rightarrow \mathrm{NO}_{2}$ & $(+)$ & $(+)$ & $(+)$ \\
\hline Nitrate respiration & $(-)$ & $(-)$ & $(-)$ \\
\hline $\mathrm{H}_{2} \mathrm{~S}$ production & $(+)$ & $(+)$ & $(+)$ \\
\hline Indol production & $(-)$ & $(-)$ & $(-)$ \\
\hline Hydrolysis of starch & $(-)$ & $(-)$ & $(-)$ \\
\hline V-P test & $(-)$ & $(-)$ & $(-)$ \\
\hline Production of acid fro & & & \\
\hline $\begin{array}{l}\text { glycerol } \\
\text { arabinose }\end{array}$ & $\begin{array}{l}(-) \\
(+)\end{array}$ & $(-)$ & $(-)$ \\
\hline xylose & $(+)$ & $(+)$ & $(+)$ \\
\hline glucose & $(+)$ & $(+)$ & $(+)$ \\
\hline fructose & $(-)$ & & \\
\hline sucrose & $(-)$ & $(-)$ & $(-)$ \\
\hline lactose & $(+)$ & $(+)$ & $(+)$ \\
\hline maltose & $(+)$ & & \\
\hline starch & $(-)$ & $(-)$ & $(-)$ \\
\hline Assimilation & & & \\
\hline glucose & $(+)$ & $(+)$ & $(+)$ \\
\hline gluconate & $(+)$ & $(+)$ & $(+)$ \\
\hline citrate & $(+)$ & $(+)$ & $(+)$ \\
\hline succinate & $(+)$ & $(+)$ & $(+)$ \\
\hline$p$-OH-benzoate & $(+)$ & $(+)$ & $(+)$ \\
\hline Growth at & & & \\
\hline $30^{\circ} \mathrm{C}$ & $(+)$ & $(+)$ & $(+)$ \\
\hline $37^{\circ} \mathrm{C}$ & $( \pm)$ & & \\
\hline $42^{\circ} \mathrm{C}$ & $(-)$ & $(-)$ & $(-)$ \\
\hline
\end{tabular}

2) Japanese Industrial Standard K 2541, "Method of Test for Sulphur in Petroleum Products by Quartztube Combustion", Japanese Standards Association, 1963.
3) S. Kinoshita and K. Hozumi, Japan Analyst, 14, 352 (1965). 
Determination of sulfur content by optical absorption spectrum of culture broth had two density

As shown in the previous paper, the visible absorption maxima at $395 \mathrm{~m} \mu$ and $470 \mathrm{~m} \mu$. The relation between sulfur content and optical density at $395 \mathrm{~m} \mu$ of the aqueous layer

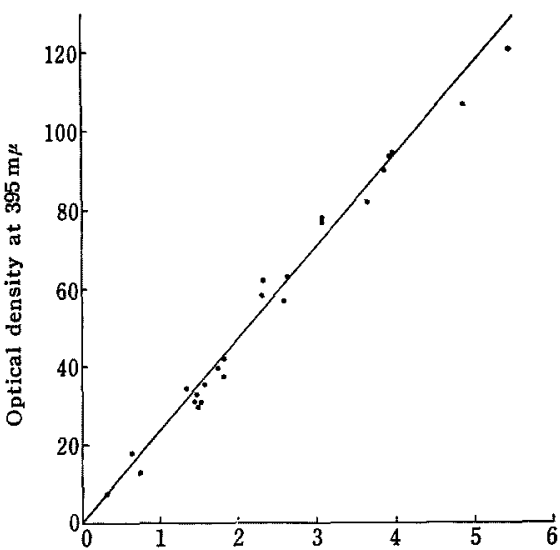

Sulfur content ( $\mathrm{mg} / 10 \mathrm{ml}$ culture filtrate)

FIG. 2. The Relationship between Optical Density and Sulfur Content of Aqueous Layer in Culture Broth. in broth is shown in Fig. 2. It is clear that there is correlation between them (correlation coefficient, $r=0.93$ ). Hence, the sulfur concentration of culture filtrate was estimated

Table II. Decomposition of DBT DISSOLVED IN LIGHT OIL

Amount of substrate Amount of sulfur

Substrate per $500 \mathrm{ml}$ flask accumulated in

DBT*

Light oil** $\widehat{\text { DBT }}$ Light oil $\begin{gathered}\text { aqueous layer } \\ (\mathrm{mg} / 100 \mathrm{ml})\end{gathered}$

Light oil

solution

of DBT

$$
0.25 \mathrm{~g}
$$

4

$0.21 \mathrm{~g} \quad 5 \mathrm{ml}$

22

* sulfur content: $17.15 \%$

** sulfur content: $0.74 \%$

Basal medium: $\mathrm{Na}_{2} \mathrm{HPO}_{4} \cdot 12 \mathrm{H}_{2} \mathrm{O} 9.5 \mathrm{~g}, \quad \mathrm{KH}_{2} \mathrm{PO}_{4}$ $1.4 \mathrm{~g}, \mathrm{MgCl}_{2} \cdot 6 \mathrm{H}_{2} \mathrm{O} 0.2 \mathrm{~g}$, meat extract $4.0 \mathrm{~g}$, distilled water $1000 \mathrm{ml}$, pH $7.3 ; 45 \mathrm{ml}$ per $500 \mathrm{ml}$ flask.

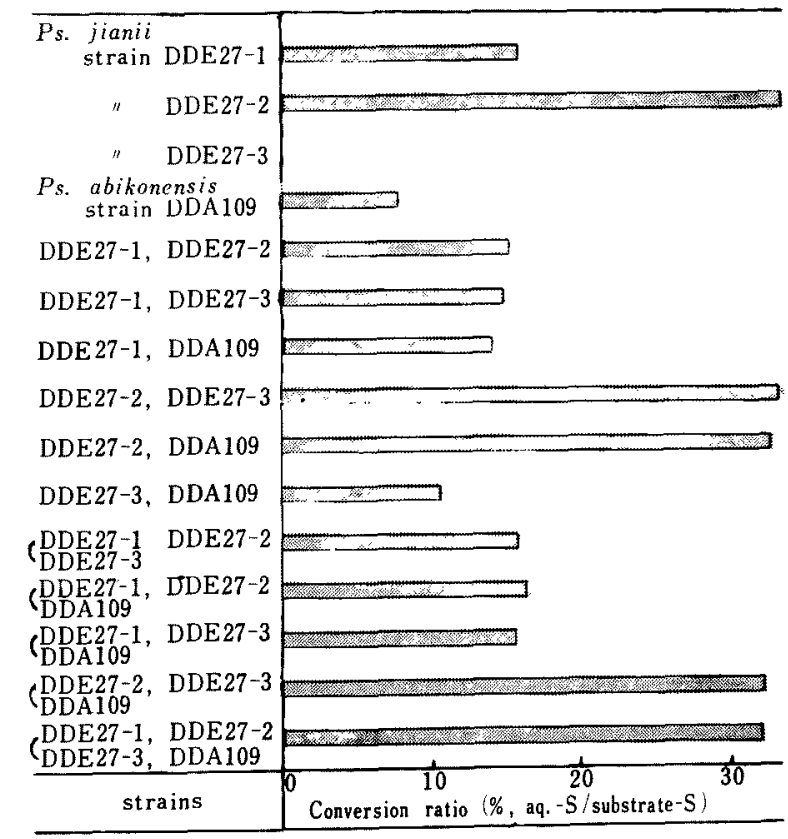

FIG. 3. Activities Converting Substrate-sulfur into Aqueous-sulfur of Isolated Strains and Their Mixed Cultures. 
spectrophotemetrically with the factor $E_{1 \mathrm{~cm}}^{1 \%}$ (at $395 \mathrm{~m} \mu)=2.35 \times 10^{3}$.

Decomposition of DBT dissolved in light oil

DBT, solid and water-insoluble at room temperature, was added to culture medium after dissolving in light oil to increase the interface of the substrate. The experimental results are given in Table II. Higher conversion efficiency was obtained with light oil solution of DBT than with powdered DBT. DBT, therefore, was used as substrate for further experiments after it was dissolved in light oil.

Comparison of activities of isolated cultures

The conversion efficiency of DBT was examined for the selection of microorganisms by their single or mixed use. The experimental results are given in Fig. 3. The activities of four other strains, DDG 327, DDE 188, DDE 206, and Ps. jianii DDC 279, were almost same to that of Ps. jianii DDE 27-1, whereas Ps. jianii DDE 27-4 did not convert DBT into water-soluble form. The good results were obtained by the mixed culture of DDE 27-2 and DDE 27-3; DDE 27-2 and DDA 109; DDE 27-2 DDE 27-3 and DDA 109; DDE 27-1, DDE 27-2, DDE 27-3, and DDA 109; and also by the single culture of DDE 27-2. The mixture of DDE 27-1, DDE 27-2, DDE 27-3, and DDA 109, accordingly, was used for further experiments.

Decrease of activity was observed in the case of mixed culture including DDE 27-1. The mixed culture of DDE 27-1, DDE 27-2, DDE 27-3, and DDA 109, however, did not decrease the activity. The reason of this exception has not yet been fully elucidated.

\section{Effect of culture conditions}

1) Nitrogen sources. In order to find out the suitable nitrogen source for the conversion of DBT, many kinds of nitrogen sources were examined. Figure 4 denotes the conversion efficiency after 5 days of incubation. Meat extract was chosen as a favorable nitrogen source and its optimum concentration was examined as presented in Fig. 5 . The best

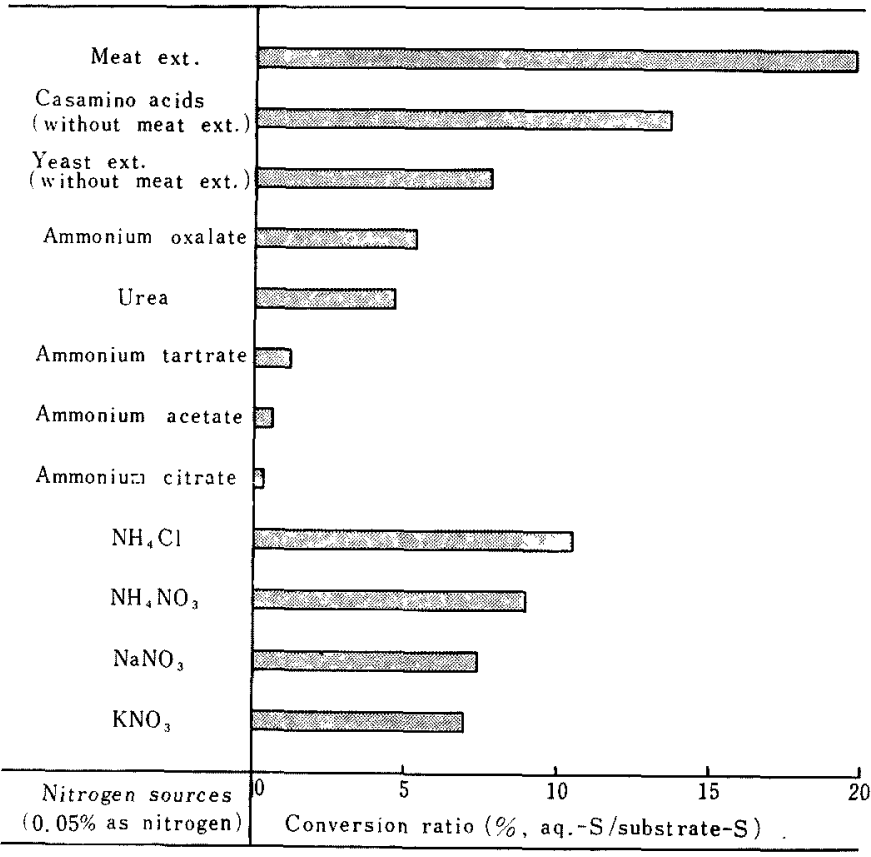

Fig. 4. Effect of Nitrogen Sources on the Conversion of DBT.

Basal medium: DBT $4.6 \mathrm{~g}$ dissolved in $87.8 \mathrm{~g}$ of light oil, $\mathrm{Na}_{2} \mathrm{HPO}_{4} \cdot 12 \mathrm{H}_{2} \mathrm{O} 9.5 \mathrm{~g}, \mathrm{KH}_{2} \mathrm{PO}_{4}$ $1.4 \mathrm{~g}, \mathrm{MgCl}_{2} \cdot 6 \mathrm{H}_{2} \mathrm{O} \quad 0.2 \mathrm{~g}$, meat ext. $0.1 \mathrm{~g}$, distilled water 1000 $\mathrm{ml}, \mathrm{pH} 7.3$. 


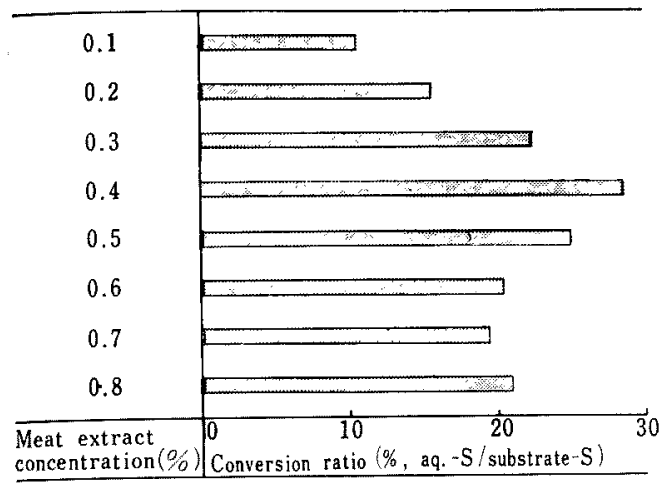

FiG. 5. Effect of Meat Extract Concentration on the Conversion of DBT.

Basal medium: same as Fig. 4.

conversion efficiency occured at the concentration of $0.4 \%$.

2) Substrate concentration. The light oil solution of DBT was added to the medium to give such concentrations as $1,2,5,10,20$, 50 , and $70 \%(\mathrm{w} / \mathrm{v})$ in the total volume of $50 \mathrm{ml}$.

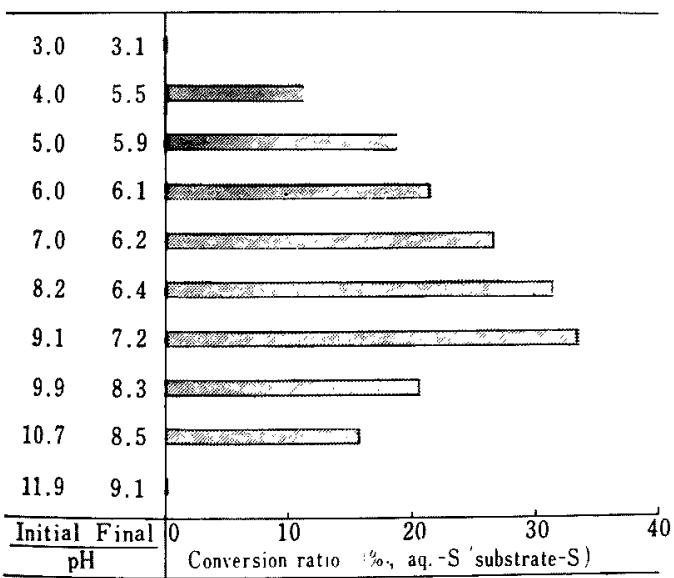

Fig. 6. Effect of Substrate Concentration on the Conversion of DBT.

Medium: DBT $4.6 \mathrm{~g}$ dissolved in $87.8 \mathrm{~g}$ of light oil, $\mathrm{Na}_{2} \mathrm{HPO}_{4} \cdot 12 \mathrm{H}_{2} \mathrm{O} 9.5 \mathrm{~g}, \mathrm{KH}_{2} \mathrm{PO}_{4} 1.4 \mathrm{~g}$, $\mathrm{MgCl}_{2} \cdot 6 \mathrm{H}_{2} \mathrm{O} 0.2 \mathrm{~g}$, meat ext. $4.0 \mathrm{~g}$, distilled water $1000 \mathrm{ml}, \mathrm{pH} 7.3$.

: Aq.-sulfur (mg)/500 ml-flask

]: Conversion ratio
Figure 6 shows the conversion ratio of DBT and the amount of aqueous sulfur accumulated in the broth after 5 days of incubation. The lower the substrate concentration was, the higher the percentage of conversion became. As substrate concentration was increased, the amount of aqueous sulfur in the broth increased and reached to the maximum at 5 to $10 \%(\mathrm{w} / \mathrm{v})$ of the substrate. It consequently, was employed in the concentration of $10 \%$ for further experiments.

3) $\mathbf{p H}$. The effect of initial $\mathrm{pH}$ on the conversion efficiency of DBT was examined

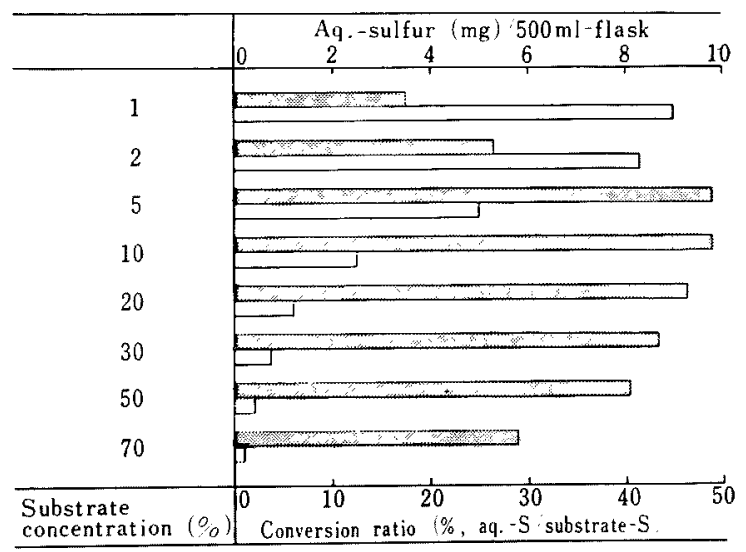

FIG. 7. Effect of $\mathrm{pH}$ on the Conversion of DBT.

Medium: DBT $4.6 \mathrm{~g}$ dissolved in $87.8 \mathrm{~g}$ of light oil, $\mathrm{KH}_{2} \mathrm{PO}_{4} 0.5 \mathrm{~g}, \mathrm{MgCl}_{2} \cdot 6 \mathrm{H}_{2} \mathrm{O} 0.2 \mathrm{~g}$, meat ext. $4.0 \mathrm{~g}$, distilled water $1000 \mathrm{ml} . \mathrm{pH}$ was adjusted to the values as indicated with $\mathrm{NaOH}$ or $\mathrm{HCl}$.

as shown in Fig. 7. The initial $\mathrm{pH}$ of 9.1 was suitable for the highest accumulation of aqueous sulfur. Since the initial $\mathrm{pH}$ of 9.1 dropped to 7.2 after cultivation, another experiment was carried out using $\mathrm{M} / 30$ phosphate buffer. The solution of $\mathrm{m} / 30 \mathrm{KH}_{2} \mathrm{PO}_{4}$ and $\mathbf{M} / 30 \mathrm{Na}_{2} \mathrm{HPO}_{4}$ were mixed duly to provide the medium to various $\mathrm{pH}$ values. The experimental results are presented in Fig. 8. The initial $\mathrm{pH}$ of 7.3 (final $\mathrm{pH}, 6.9$ ) appeared to be optimum for the conversion of DBT in 5 days of incubation. 


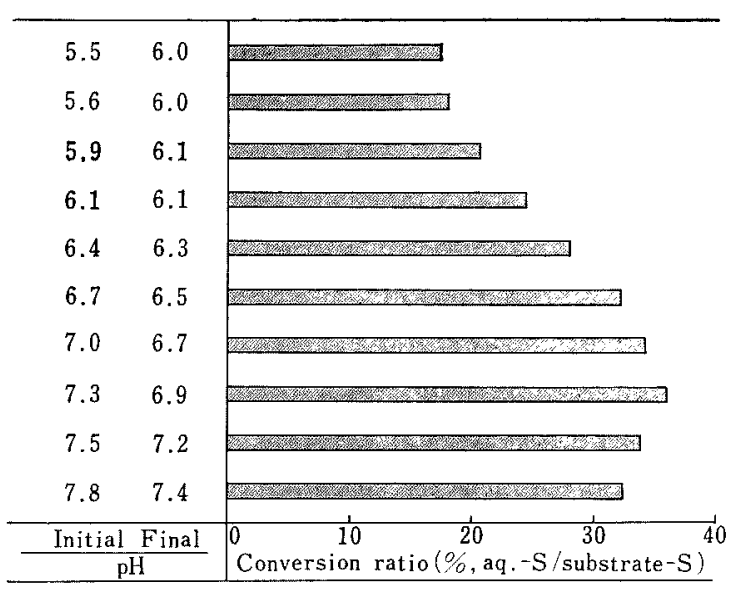

FIG. 8. Effect of $\mathrm{pH}$ Buffered with $\mathrm{M} / 30$ Phosphate Solution on the Conversion of DBT.

Medium: DBT $4.6 \mathrm{~g}$ dissolved in $87.8 \mathrm{~g}$ light oil, $\mathrm{Na}_{2} \mathrm{HPO}_{4} \cdot 12 \mathrm{H}_{2} \mathrm{O} \quad 0.4 \mathrm{~g}$ to $11.2 \mathrm{~g}, \mathrm{KH}_{2} \mathrm{PO}_{4}$ $0.8 \mathrm{~g}$ to $4.9 \mathrm{~g}, \mathrm{MgCl}_{2} \cdot 6 \mathrm{H}_{2} \mathrm{O} 0.2 \mathrm{~g}$, meat ext. $4.0 \mathrm{~g}$, distilled water $1000 \mathrm{ml}$.

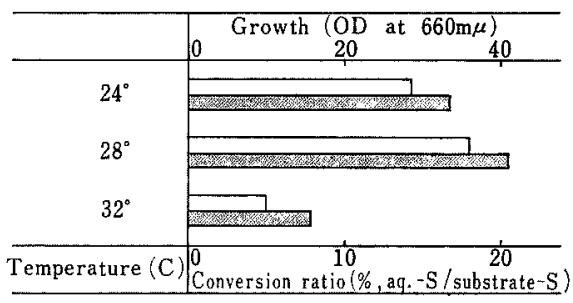

Fig. 9. Effect of Temperature on the Conversion of DBT.

Medium: same as Fig. 6.

$\square:$ Growth (OD at $660 \mathrm{~m} \mu)$

च: Conversion ratio

4) Temperature. The effect of temperature was investigated. The results obtained are shown in Fig. 9. The activity was higher at $28^{\circ} \mathrm{C}$ than $24^{\circ} \mathrm{C}$ and $32^{\circ} \mathrm{C}$. The optimum temperature for DBT-utilization and for growth were same in this culture.

5) Oxygen supply. The effect of oxygen supply on the conversion efficiency was investigated by the shaking culture with the medium of $20 \mathrm{ml}$ to $100 \mathrm{ml}$ in a $500 \mathrm{ml}$ flask. The highest conversion of DBT was obtained with $20 \mathrm{ml}$ of the medium (Fig. 10). This result suggests that vigorous aeration is favorable for the conversion of DBT.

Time course of cultivation. Figure 11 shows the time course of cultivation by the mixed culture of Ps. abikonensis, Ps. jianii DDE 27-1, DDE 27-2 and DDE 27-3. Aqueous sulfur was formed in a relatively short time, and the highest level (conversion ratio 40\%) was at-

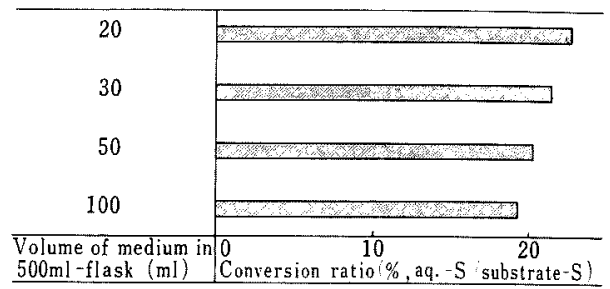

FIG. 10. Effect of Aeration on the Conversion of DBT.

Medium: DBT $4.6 \mathrm{~g}$ dissolved in $87.8 \mathrm{~g}$ of light oil, $\mathrm{KH}_{2} \mathrm{PO}_{4} 0.5 \mathrm{~g}, \mathrm{MgCl}_{2} \cdot 6 \mathrm{H}_{2} \mathrm{O} 0.2 \mathrm{~g}$, meat ext. $4.0 \mathrm{~g}$, distilled water $1000 \mathrm{ml}$, pH 9.0.

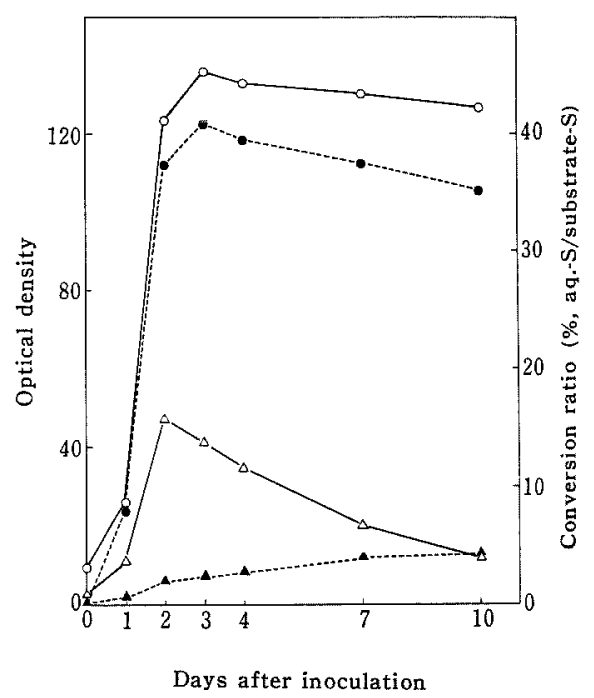

FIG. 11. Time Course of Cultivation.

Medium: same as Fig. 6.

----: Conversion ratio,

-O-: OD at $395 \mathrm{~m} \mu$,

----: Growth (OD at $660 \mathrm{~m} \mu$ ),

$-\triangle-:$ OD at $470 \mathrm{~m} \mu$ 
tained on the third day. Optical density at $470 \mathrm{~m} \mu$ reached a peak on the second day and thereafter decreased. The curve of cell growth had not similar tendency to that of conversion of DBT.
Acknowledgment. The authors wish to express their deepest appreciation to Dr. K. Komagata (Central Research Laboratories, Ajinomoto Co., Inc.) for his kind help in taxonomic studies. 